\title{
Access and Reward in the Information Society: Regulating the Collective Management of Copyright
}

\author{
Martin Kretschmer ${ }^{*}$
}

\begin{abstract}
Copyright Collecting Societies have proliferated, with more than 150 organisations now collecting and distributing licensing fees for rights in music, literary, audio-visual and graphic works within the European Union. From the perspective of Competition Law, collecting societies may be viewed as price-fixing cartels under Art. 81 EC, and as vulnerable to challenges under Art. 82 EC (i.e. abusing a dominant position as the sole provider of a management infrastructure to right holders, and as the only supplier of licences to copyright users). Yet, collective administration of copyright has important policy benefits: (i) From a user perspective, collecting societies may offer a single point licence providing easy and wide access to copyright protected contents. This can be a solution to innovation issues in an information society where major right holders otherwise may dictate problematic terms. (ii) Creators at the margins of commercial viability have access to a mechanism of collective bargaining against major rights exploiters, such as publishers, record labels and broadcasters. This may support a culturally diverse society. This article develops principles for regulating the collective management of copyrights from a critique of EC competition jurisprudence.
\end{abstract}

Key words: copyright, collecting societies, collective administration, competition, information society

\footnotetext{
* Professor of Information Jurisprudence, Centre for Intellectual Property Policy \& Management (www.cippm.org.uk), Bournemouth University; Visiting Professorial Fellow, Queen Mary Intellectual Property Research Institute, University of London. Earlier versions of this paper were delivered at the $6^{\text {th }}$ National Intellectual Property Workshop (Cambridge, 27 June 2005), and at the annual congress of the Society for Economic Research on Copyright Issues (Montréal, 7-8 July 2005). I also benefited considerably from discussions at a Max-Planck-Institute workshop on the law of collecting societies (Munich, 13 February 2007). Changes made in response to comments received on these occasions are acknowledged in the footnotes.
} 


\section{Introduction}

Copyright collecting societies are complex institutions. Outsiders, and even insiders, have found it difficult to understand the rights they manage as well as their tariff and distribution structures. The principles governing the relationship between licensors and licensees are poorly articulated. Yet, by providing access to information goods and rewarding creators and investors of copyright-protected materials, collecting societies are integral to the structure of an information society.

Copyright societies have been likened to joint ventures, trustees, mutual societies and collecting agents. In some countries, they are constituted as corporate non-profit organisations (UK), in others they may operate under a government monopoly grant (Austria, Italy, Japan). Most European societies are somewhat in the middle, constituted as private membership associations but subject to close regulatory supervision. This may include formal permissions to operate a collecting society, statutory obligations regarding membership rules, accounting procedures and licensing conditions, or tariffs set directly by government (e.g. levies on blank tapes, recordable discs and copying equipment). ${ }^{1}$

In the UK, there are currently 13 collective licensing bodies, some managing very valuable primary rights, such as the music rights to public performance and broadcasting assigned to the Performing Right Society PRS, or the right to make and distribute recordings for which the Mechanical-Copyright Protection Society MCPS acts as exclusive agent. The largest societies exercise considerable economic clout. In

\footnotetext{
${ }^{1}$ For surveys of the different constitutions of European Collecting Societies, see Carine Doutrelepont, Le contrôle des sociétés de gestion des droits d'auteur et des droits voisins dans la Communauté européenne (Brussels: Bruylant, 1995); Paul Katzenberger, 'Die verschiedenen Systeme des Aufsichtsrechts über die kollektive Verwertung von Urheberrechten in den europäischen Staaten’, pp. 1-15 in R.M. Hilty ed. (1995) Die Verwertung von Urheberrechten in Europa; KEA report commissioned by European Parliament The Collective Management of Rights in Europe (July 2006). For an international comparative study from a Canadian perspective, see Daniel J. Gervais, 'Collective Management of Copyright and Neighbouring Rights in Canada: An International Perspective' (2002) 1(2) Canadian Journal of Law and Technology 21-50. The European Commission is not particularly concerned about the legal status of collecting societies which 'may be corporate, charitable, for profit or not for profit entities' (Communication COM(2004) 261: The Management of Copyright and Related Rights in the Internal Market, para 3.5.1).
} 
2006, the international umbrella body Confédération Internationale des Sociétés

d'Auteurs et Compositeurs (CISAC) had 217 members from 114 countries, with a total annual turnover of more than $€ 6,5$ billion. $^{2}$

From the perspective of European competition law, collecting societies prima facie appear extremely problematic. As Aitman and Jones suggest: 'The Commission is generally hostile to any form of collective selling or sales ventures, selling the products of competing manufacturers, as they restrict competition between the parents on the supply side and limit the choice of purchasers. They are effectively horizontal price fixing agreements prohibited by Art. 81(1) when they have an appreciable effect on the market.' 3

Thus it may seem surprising that collecting societies feature heavily in EU copyright policies. Some rights harmonised by Directives, such as the rental right, cable retransmission and the droit d'suite may only be exercised through collecting societies. ${ }^{4}$ Recital (17) of the Information Society Directive singles out the need for efficient collective administration. ${ }^{5}$

\footnotetext{
2 Data available on the CISAC website (www.cisac.org). The UK collective licensing bodies are: Authors Licensing \& Collecting Society (ALCS) - administers certain rights in the literary and dramatic copyright area (payments 2003: £12,6 million); Christian Copyright Licensing International (CCLI) - licenses the reproduction of songs and hymns; Copyright Licensing Agency (CLA) - licenses reprographic copying of literary works; Design and Artists Copyright Society (DACS) - administers reproduction rights for visual artists (revenues 2003: £3m); Educational Recording Agency Ltd (ERA) - licenses recording off-air by educational establishments; The International Federation of the Phonographic Industry (IFPI) - licenses use of foreign sound recordings not commercially available in the UK; Mechanical-Copyright Protection Society (MCPS) - licenses the making and distribution of sound recordings (payments 2003: £226 million); Newspaper Licensing Agency (NLA) - issues licences for copying of newspapers; Performing Artists' Media Rights Association (PAMRA) collects and distributes royalties to performers for use of sound recordings; Performing Right Society (PRS) - licenses public performances and broadcasting of music (revenues 2003: $£ 283$ million; payments 2003: £242 million); Phonographic Performance Limited (PPL) - licenses certain uses of copyright sound recordings; Publishers Licensing Society (PLS) - administers certain rights on behalf of publishers; Video Performance Limited (VPL) - licenses certain uses of music video recordings (source: annual reports). By my own estimate, there are currently more than 150 collecting societies acting for right holders in the EU alone (about 65 core music licensing societies, about 40 core reprographic societies licensing printed materials and numerous miscellaneous collective managers). Europe's largest society is Germany's GEMA (administering music performing and mechanical rights) with an annual turnover exceeding $€ 800 \mathrm{~m}$ (annual report 2003).

${ }^{3}$ D. Aitman and A. Jones, 'Competition Law and Copyright: Has the copyright owner lost the ability to control his copyright?' (2004), 3 European Intellectual Property Review 137-147, at 144.

${ }^{4}$ Article 4, Council Directive 1992/100 on the rental right and lending right and on certain rights related to copyright in the field of intellectual property; Article 9, Council Directive 1993/83 on the coordination of certain rules concerning copyright and rights related to copyright applicable to
} 
In this article, I argue that the policy attraction of collective licensing in a digital environment consists in two features:

From a user perspective, collecting societies may offer a single point licence providing easy and wide access. This can be a solution to innovation issues in the information society where major right holders otherwise may dictate problematic terms.

Creators at the margins of commercial viability have access to a mechanism of collective bargaining against major rights exploiters, such as publishers, record labels and broadcasters. This may be an important support mechanism in fostering a culturally diverse society.

The European Courts and the European Commission have been unable to articulate these important aims clearly, perhaps because they cannot be easily placed within the framework of Community competencies. (a) Copyright as a territorial right is asserted and enforced nationally. Limitations on the exclusive nature of intellectual property can only be placed where the exercise of intellectual property rights conflicts with the free movement of goods and the rules of competition. ${ }^{6}$ (b) A common cultural policy is not a recognised Community activity under Article 3 EC Treaty, although the Maastricht additions to Article 3 (1992) recognise 'a contribution ... to the flowering of cultures of the Member States'. ${ }^{7}$

satellite broadcasting and cable retransmission; Article 6, Council Directive 2001/84 on the resale right for the benefit of the author of an original work of art.

${ }^{5}$ Council Directive 2001/29 on the harmonisation of certain aspects of copyright and related rights in the information society, Recital (17): 'It is necessary, especially in the light of the requirements arising out of the digital environment, to ensure that collecting societies achieve a higher level of rationalisation and transparency with regard to compliance with competition rules.' The ambition to incorporate the regulation of copyright societies into the Information Society Directive was indicated in the 1995 Green Paper Copyright and Related Rights in the Information Society (COM(95) 382) but later dropped.

${ }^{6}$ In Lagardère v SPRE, GVL and CERT (Case C-192/04; judgment of 14 July 2005) concerning a broadcasting signal directed at the French market but using terrestrial transmitters in French and German territory, the ECJ reaffirmed the territorial nature of copyright and related rights 'which is recognised in international law and also in the EC Treaty'. The legislation of both states was applicable in determining equitable remuneration for the performers and producers of phonograms. The opinion of AG Tizzano (at para 61) refers to Article 11bis of the Berne Convention (Paris Act 1971) stating that 'it shall be a matter for the legislation in the countries of the Union [established by the Convention] to determine the conditions under which the rights [in question] may be exercised, but these conditions shall apply only in the countries where they have been prescribed'.

${ }^{7}$ A new Article 151 also provides that cultural aspects must be 'taken into account' in Community actions (including developing single market and competition policies). 
The argument in this paper is structured to expose the roots of this tension. In section two, I briefly introduce the historical shape of collecting societies, in particular 'transaction cost' and 'solidarity' explanations of their origins are advanced, and the dilemma of joint creator and investor representation is explicated. In section three, I review the jurisprudence of Commission and European Courts over three decades with respect to the collecting societies. In a nutshell, collecting societies are dominant economic undertakings subject to the rules of competition. They have to provide user licences on reasonable terms, and give their members maximum freedom to administer their rights individually consistent with the societies' function. However, I show that the societies' function cannot be easily articulated in competition terms. In section four, recent regulatory measures proposed by the European Commission are set in this context (in particular: Communication COM(2004) 261 The Management of Copyright and Related Rights in the Internal Market; Staff Working Document Study on a Community Initiative on the Cross-Border Collective Management of Copyright, 7 July 2005; Commission Recommendation On the Collective Crossborder Management of Copyright and Related Rights for Legitimate Online Music Services, adopted 12 October 2005). It is argued that the management of copyright and related rights should be placed in the context of innovation policy in culturally diverse societies, regulating collecting societies from first principles of access and reward.

\section{Characteristics of Collecting Societies}

The origins of collective administration may appear as a straightforward response to a problem of transaction costs. An evocative story recounts the visit of Ernest Bourget, a French composer of popular chansons and chansonettes comiques, to the Paris café Ambassadeurs in 1847 where, among other pieces, his music was being played without permission. He then refused to settle the bill for his drink of sugared water, at the time a fashionable beverage. In the resulting brawl, M. Bourget argued 'you consume my music, I consume your wares' - an argument he won before the Tribunal de Commerce de la Seine which upheld a revolutionary law of 1793, recognising a right to public performance for the first time. ${ }^{8}$

\footnotetext{
8 The French Acts of 1791 (regarding performances of theatre and musical drama) and 1793 (regarding the sale and dissemination of artistic works of any genre) replaced the old system of publishers' rights
} 
Ernest Bourget understood that as an individual composer he should not devote his life to chasing unauthorised performances of his music. Vice versa, each venue performing popular music would incur considerable costs in tracking and negotiating with various holders of the relevant performing rights. The solution to the failures of individual contracting was collective administration, combining a comprehensive monitoring service of music usage with a facility to issue licenses, i.e. permissions to play against remuneration. Ernest Bourget, his colleagues Victor Parizot and Paul Henrion as well as the publisher Jules Colombier founded an Agence Centrale, the direct predecessor of the first modern collecting society Société des Auteurs et Compositeurs et Editeurs de Musique (SACEM). SACEM, established in 1851, became the European model, collecting at times even in Switzerland, Belgium and the UK.

Transaction cost economics recognises that there are costs of using markets, such as as information costs, contract costs and governance costs. ${ }^{9}$ In the case of copyright, transaction costs may include (a) identifying and locating the owner, (b) negotiating a price (this includes information and time costs), (c) monitoring and enforcement costs. The sparse economic literature on collecting societies tends to accept a transaction cost rationale for their existence. ${ }^{10}$

with a system of authors' rights. For details of the Bourget case, see F. Melichar Die Wahrnehmung von Urheberrechten durch Verwertungsgesellschaften (München: Schweitzer, 1983).

9 Thus, under certain conditions, non-market structures (such as integrating economic activities into the hierarchy of a firm) can be more efficient than individual contracting. O.E. Williamson, Markets and Hierarchies: Analysis and antitrust implications (New York: Free Press, 1975); O.E. Williamson, The Economic Institutions of Capitalism: Firms, markets, relational contracts (New York: Free Press, 1985).

10 A. Hollander 'Market Structure and Performance in Intellectual Property: The Case of Copyright Collectives' (1984) 2 International Journal of Industrial Organization 199-216; S.M. Besen and S.N. Kirby Compensating Creators of Intellectual Property: Collectives that collect (Santa Monica, CA: RAND, 1989); S.M. Besen, S.N. Kirkby and S.C. Salop 'An Economic Analysis of Copyright Collectives' (1992) 78 Virginia LR 383; John Kay 'The Economics of Intellectual Property Rights' (1993) 13 International Review of Law and Economics 337-348; Ruth Towse 'Copyright as an Economic Incentive', in 'Innovation, Incentive and Reward: Intellectual Property Law and Policy' (1997) 5(1) David Hume Papers on Public Policy 31-45; Jeremy Thorpe (1998), 'Regulating the Collective Exploitation of Copyright' (1998) in special issue: Trade and Intellectual Property (ed. P. Drahos), 16(3) Prometheus 317-329; W.M. Landes and R.A. Posner The Economic Structure of Intellectual Property Law, chapter 14 (Cambridge, Mass: Belknap/Harvard, 2003). 
Under collective administration, there is typically only one supplier of licences to the user of copyright works in one particular domain of rights (such as public

performances). Reciprocal agreements with sister societies in other countries ensure that access to 'the world repertoire' can be granted through one licence. From the perspective of individual owners of copyright works, there may be no alternative provider of a rights administration infrastructure. In consequence, market prices cannot form either for licences to users nor for services to right holders. ${ }^{11}$

This monopolistic structure leaves copyright collecting societies in control of the terms of access and royalty distribution in their particular rights domain. In many areas of collective licensing, administrative costs are extremely high. The cost of collection may amount to a quarter of revenues - while for other complex services (such as health insurance) administrative deductions of 5\% are seen as high. ${ }^{12}$

The tendency of collective administration to evolve into self-serving bureaucracies sheltered from competition has led to increasing state involvement in the supervision of collecting societies. As a general rule, collecting societies in all EU Member States cannot refuse to license their repertoire; they have to admit members subject to certain threshold rules; and they have to give some kind of public account of their finances.

\footnotetext{
11 One strand of commentators has located the inefficiencies in collective administration in the nature of liability rules: R.P. Merges 'Contracting into Liability Rules: Intellectual Property Rights and Collective Rights Organizations' (1996), 84 California Law Review 1293. The argument derives from R.H. Coase's seminal paper 'The Problem of Social Cost' (1960), 3 Journal of Law and Economics 144. For a critique of natural monopoly analysis, see A. Katz 'The Potential Demise of Another Natural Monopoly: Rethinking the Collective Administration of Performing Rights' (2005) 1(3) Journal of Competition Law and Economics 541, and 'The Potential Demise of Another Natural Monopoly: New Technologies and the Administration of Performing Rights' (2006) 2(2) Journal of Competition Law and Economics 245.
}

12 To give some examples: PRS performing right income is roughly equally split between income from broadcasting and from general performance (i.e. music at pubs, clubs, shops, aircrafts, concerts). Unsurprisingly, the costs of collecting are much higher for the latter. For 1999, the PRS reported income of $£ 75.54 \mathrm{~m}$ from general licensing (of which $24.5 \%$ disappeared as administrative commission) and $£ 79.58 \mathrm{~m}$ from broadcasting (with $14.6 \%$ deducted for administrative expenses), leaving a net distribution of $£ 57 \mathrm{~m}$ and $£ 68 \mathrm{~m}$ respectively (PRS Yearbook 2000/01). The Design and Artists Copyright Society (DACS) administers reproduction rights for visual artists (painters, printmakers, sculptors, and photographers). Of the turnover of $£ 3 \mathrm{~m}$ in $2003,25 \%$ are charged as administration costs (Annual Report 2004). Analytical tools for analysing the efficiency of collecting societies are discussed in F. Rochelandet 'Are Copyright Collecting Societies Efficient?' paper presented at the annual congress of the Society for Economic Research on Copyright Issues, Madrid 2002 [available at www.serci.org]. See also A. Charnes, W.W. Cooper, and E. Rhodes 'Measuring the efficiency of decision making units' (1978) 2 European Journal of Operational Research 429-444. 
In the case of music performing right and mechanical reproduction societies, the most intriguing feature of collective administration is the representation of both authors (composers and lyricists) and publishers - enforced by a governance structure under which changes to membership and distribution rules can only be implemented by mutual consent of both groups. Despite market pressures to the contrary, author members of German society GEMA receive 70\% (compared to $30 \%$ of the publisher) of any performing right royalty distribution, and $60 \%$ of the mechanical rights. PRS distributes 50:50 between publishers and creators, while MCPS leaves the distribution shares to individual contracts between the parties. ${ }^{13}$ In addition, large right holders whose works are easier to monitor and account for, in effect subsidise small members. These distribution decisions are treated as internal matters, and will not be publicised.

Many European collecting societies also weigh their distribution per copyright work according to a value judgment, including the amount of skill involved, and the cultural contribution of a genre or composer. ${ }^{14}$ Finally, under the guidelines of CISAC (Confédération Internationale des Sociétés d'Auteurs et Compositeurs), the international umbrella organisation of the author rights societies, up to $10 \%$ of collected licence fees may be channelled into socio-cultural funds. ${ }^{15}$

\footnotetext{
${ }^{13}$ Naturally, it is hard to know what would be a market rate in the absence of a market, a point put to me by Prof. Stan Liebowitz at the Montréal conference (and argued elsewhere, e.g. 'Alternative Copyright Systems: The problems with a compulsory license', a 2003 manuscript available on his website (http://www.utdallas.edu/ liebowit/). Two observations indicate to me that the royalty fees available to music writers are above what would be negotiated in a competitive market between willing individual sellers and buyers: (i) they are very high compared to other markets, such as performers, or video game developers; (ii) authors are under pressure from publishers to accept (and have accepted) a lower percentage of the royalty distribution in countries without a tradition of collective author organisation (such as the 10 new EU members which acceded in 2004).

14 At GEMA, so-called 'evaluation committees' weighs the distribution of royalties to authors from considerations of length of membership, past income, artistic personality and overall contribution of an œuvre. In the UK, the classical music subsidy in the royalty distribution formula was phased out following the MMC report of 1996 (Monopolies and Mergers Commission Performing Rights, London: HMSO Cm 3147). In 1999, a PRS foundation was established for the support of new music, regardless of genre.

15 The German law regulating copyright societies (Urheberwahrnehmungsgesetz) explicitly demands that they should foster 'culturally important works and contributions' (\$7) and set up pension and social funds (§8). Anglo-American right holders are enraged by these deductions. They feel that their exported property subsidises foreign social and cultural policy: A. Harcourt, A. (1996), 'The Unlawful Deduction Levied upon UK Composers' Performing Rights Income' (1996) 64 Copyright World 15. I address this argument below.
} 
The analysis suggests that collective administration can also be viewed as a form of unionisation. Authors no longer enter the market as individuals. ${ }^{16}$ This enables them to extract better terms than contracting individually with music publishers and music users (such as labels and broadcasters), and provide socio-cultural support to creators.

In summary, the features of European Collecting Societies are:

\section{Characteristics under transaction cost rationale}

- two fold monopolists (towards users and members)

- administration cannot be refused

- licence cannot be refused

\section{Characteristics under solidarity rationale}

- publishers' control below market expectations

- socio-cultural deductions for the benefits of domestic creators

- cross-subsidy between big and small right holders

- discrimination between genres

\section{Commission and ECJ Jurisprudence ${ }^{17}$}

\section{General: The exclusive territorial nature of intellectual property rights}

The exercise of exclusive intellectual property rights in itself should not give rise to competition concerns, since it is the purpose of intellectual property laws to provide for dynamic efficiencies through periods of exclusive territorial protection. The early jurisprudence of the ECJ ${ }^{18}$ developed a distinction between the existence of intellectual property rights (which was seen as outside the EC Treaty) and their exercise (which can be reviewed under Community law). As AG Fennelly correctly

\footnotetext{
16 A. Peacock and R. Weir The Composer in the Market Place (London: Faber, 1975) at 41.

17 Throughout this review of EC jurisprudence, the re-numbering of Articles 85 and 86 EC as Articles 81 and 82 is adopted (Treaty of Amsterdam). In citations prior to 1 May 1999, the old article numbers are replaced with the new [indicated by brackets].
} 
argues in Merck $I I^{19}$, this doctrine is fallacious. Intellectual property rights are provided in order to be exercised. Otherwise there would be no point to their grant, since the incentives to create and innovate would disappear. In the more recent line of jurisprudence emanating from Coditel $I I^{20}$, the Court recognised that absolute territorial protection under exclusive copyright licence agreements does not in itself infringe Article 81(1) EC. In Magill ${ }^{11}$ the Court stressed that the exercise of intellectual property rights would be examined under Article $82 \mathrm{EC}$ only under exceptional circumstances: in this case findings of a dominant position plus failing to meet demand for a new product in a secondary market for which there is no substitute.

Thus, the collective administration of copyright would have to be shown to be beyond the normal exercise of intellectual property rights. Before considering the case law in detail, two arguments need to be considered placing collecting societies beyond acquis communitaire examination under the prohibition on quantitative restrictions (Articles 28-30 EC), and under the competition rules applying to undertakings (Articles 81-82 EC).

\section{Do the rights administered by collecting societies fall under the obligations regarding the free movement of goods (Articles 28-30, EC Treaty)?}

During the 1970s, a case was made that author rights do not constitute 'industrial or commercial property' within the meaning of Article 30, and therefore Treaty obligations regarding the free movement of goods would not apply. For example, the nature of copyright under international treaties includes non-economic author rights that cannot be transferred as property: chiefly the right to paternity (the right to be named as the author) and the right to integrity (the right to object to modifications of a work that would prejudice the author's reputation). ${ }^{22}$ The ECJ has consistently refused to distinguish literary and artistic property in this way, asserting that 'the

\footnotetext{
18 Cases 56 and 58/64: Consten \& Grundig v. Commission [1966] ECR 229, [1966] CMLR 418; Case 78/70, Deutsche Grammophon Gesellschaft v. Metro-SB-Großmärkte GmbH [1971] ECR 487, [1971] CMLR 631.

${ }^{19}$ Cases C-267 and 268/95: Merck v. Primecrown [1996] ECR I-6285, [1997] 1 CMLR 83.

${ }^{20}$ Case 262/81, Coditel v. SA Ciné Vog Films [1982] ECR 3381, [1983] 1 CMLR 49.

${ }^{21}$ Cases C-241\&2/91, RTE \& ITP v. Commission [1995] ECR 1-743; [1995] 4 CMLR 586.

22 So-called droit moral: Berne Convention, Art. 6bis.
} 
exclusive rights conferred by literary and artistic property are by their nature such as to affect trade in goods and services and also competitive relationships within the Community.'23

\section{Do collecting societies fall under the rules of competition (Articles 81-82, EC}

\section{Treaty)?}

When the behaviour of collecting societies was first challenged under Articles 81 and 82 , they attempted to invoke Article $86(2)$ as being entrusted by the state "with the operation of services of general economic interest', a provision that permits in certain circumstances derogation from the rules of competition. In $B R T$ v. SABAM ${ }^{4}$ (1974), the first collecting society case before the European Courts, the ECJ characterised the Belgian performing right society as 'an undertaking to which the state has not assigned any task and which manages private interest, including intellectual property rights protected by law'. This was confirmed in 1979 and 1983 in the Greenwich ${ }^{25}$ and $G V L^{26}$ cases.

\section{Agreements and concerted practices (Art. 81 EC issues)}

In one reading, collecting societies are joint ventures creating a super-dominant market position in at least two respects: towards users and right holders. Thus it is surprising that their very existence has not been challenged under Article $81 .^{27}$

\footnotetext{
23 Case C-92/92, Phil Collins v. IMTRAT Handels GmbH, [1993] 3 CMLR 773 (para. 22). Cf. W. Cornish and D. Llewelyn Intellectual Property ( $5^{\text {th }}$ ed.) (London: Sweet \& Maxwell 2003), section 182.

24 Case 127/73, Belgische Radio en Televisie v. SV SABAM and NV Fonior, [1974] ECR 313, [1974] 2 CMLR 238.

25 Case 22/79, Greenwich Film Production, Paris v. SACEM, [1979] ECR 3275, [1980] 1 CMLR 629.

${ }^{26}$ Case 7/82, Gesellschaft zur Verwertung von Leistungsschutzrechten mbH (GVL) v. Commission, [1983] ECR 483; [1983] 3 CMLR 645.

27 This point was made by J. Temple Lang, then a director in DG Competition ('Media, Multimedia and European Community Antitrust Law' (1998) 21 Fordham International Law Journal 1296): 'The assumption that no member or group of members of a society could negotiate licences is no longer true, if it ever was, of big sound reproduction companies which can do and do, enter into individual negotiations, in particular for reproduction rights, when the size and importance of the licensee makes it worthwhile to do so. It seems to follow that as far as such companies are concerned the main reason for ignoring Article [81(1)] is no longer convincing, and such companies need exemption under Article [81(3)] for their participation in these societies, at least in their relations with licensees which are important enough to make individual negotiations appropriate. It is surprising that this issue has not been raised before now.'
} 
Three lines of reasoning could be constructed.

(i) The agreements constituting collecting societies form part of a process of collective bargaining. The leading cases here are Albany International and Brentjens $^{28}$ in which the ECJ ruled that agreements on compulsory pension schemes fall outside the scope of Article 81. To my knowledge, this argument has not been tried on collective administration agreements.

(ii) In the 1989 Tournier and Lucazeau cases $^{29}$, French Discothèques challenged SACEM's reciprocal representation agreements with other collecting societies (ensuring domestic exclusivity) that prevented direct access to the Anglo-American repertoire the appellants were interested in. The ECJ held that the reciprocal agreements between societies may not fall under Art. 81(1) provided no concerted action was evidenced, and there was another reason for these agreements. 'Such a reason might be that the copyright-management societies in other Member States would be obliged, in the event of direct access to their repertoires, to organize their own management and monitoring system in another country.' (Lucazeau at para 18; Tournier at para 24)

(iii) A third line of reasoning would concede that both, agreements constituting collecting societies, and reciprocal representation contracts fall within Art. 81(1) and seek exemption under Art. 81(3). This would be consistent with the view taken by the Commission in other instances of collective licensing agreements, such as sport broadcasting and joint film distribution. In a statement of objections to the English Premiere League

\footnotetext{
${ }^{28}$ Case C-67/96, Albany International BV v. Stichting Bedrijfspensioenfonds Textielindustrie [1999] ECR I-5751, [2000] 4 CMLR 446; Cases C-115 to 117/97, Brentjens v. SBVHB, [1999] ECRI-6025, [2000] 4 CMLR 566. AG Jacobs opinion in Albany laid down four conditions for disapplying Art. 81. The collective bargaining agreement (i) was made as part of normal collective bargaining, (ii) was made in good faith, rather than to conceal anti-competitive restrictions, (iii) dealt with core aspects of collective bargaining, such as wages or other conditions of work, and (iv) did not affect third parties. For discussion, see D.G. Goyder EC Competition Law (4 ${ }^{\text {th }}$ ed.), (Oxford: OUP, 2003) pp. 104-5.

${ }^{29}$ Cases 110/88, 241/88, 242/88, Lucazeau and others v. SACEM; Case 395/87, Ministère Public v. Tournier. All at [1989] ECR 2811, [1991] 4 CMLR 248. At paragraph 11, the reciprocal representation contract is specified: 'each society is to apply, with respect to works in the other society's repertoire, the same scales, methods and means of collection and distribution of royalties as those which it applies for works in its own repertoire.'
} 
broadcasting rights arrangements ${ }^{30}$, the Commission argues that the characteristics of sport, such as the need for solidarity, can be taken into account under Art. 81(3). However, restrictive provisions that foreclose the market would not be indispensable to the benefits of the agreement (guaranteeing solidarity between clubs). Similarly, in the UIP decision ([1989] OJ L226/356), a joint film distribution agreement was exempted under Art. 81(3) as it produced economic benefits for the production and distribution of motion pictures and for consumers.

It turns out that there are a number of agreements between collecting societies and users that have been treated in this way under the old notification procedure. ${ }^{31}$ They all respond to Internet demands for a single pan-European licence while attempting in some ways to safeguard a role for national collecting societies. The models proposed fall into three broad categories.

a. Agreements were licence conditions are harmonised (each society can issue a single pan-European licence but under fixed terms). ${ }^{32}$

b. Agreements where each participating society can issue a single panEuropean licence but the tariff applied is that of the country of destination (Simulcasting agreement). ${ }^{33}$

c. Agreements where each participating society can issue a single panEuropean licence but the licence will be granted by the society of the

${ }^{30}$ A provisional settlement was announced in IP/03/1748. For discussion, see Aitman and Jones 2004, p. 146 , n. 66.

${ }^{31}$ Regulation 17/62 [1959-62] OJ Spec. Ed. 87. Since 1 May 2004, this has been replaced by Regulation 1/2003 [2004] OJ L1/1 which decentralises enforcement of Articles 81 and 82.

32 There is currently no operational example of this type of agreement. COM(2004) 261 (The Management of Copyright and Related Rights in the Internal Market, at para 1.2.4) refers to the OnLineArt Agreement initiative for a Community-wide licence for on-line uses of works of art and photography.

33 Case COMP/C2/38.014, IFPI Simulcasting, [2003] OJ L107/58: Agreement between national record producers' collecting societies, licensing sound recordings for pan-European simultaneous Internet transmissions of broadcasts (notified by IFPI: International Federation of the Phonic Industry). The Commission decided that Art. 81(3) was met, as the agreement created a new product that would improve the distribution of music to the benefit of consumers. The clause applying the tariff of the country of destination was ruled to be restrictive, going beyond what is necessary for the existence of the agreement. However, societies would not participate without that clause. The agreement also would create competition between societies. Transparent separation of administrative costs was agreed: 'This way, commercial users will be able to recognise the most efficient societies in the EEA and seek their licences from the collecting societies that provide them at lower cost.' (COM 261 3.4(iii)) 
country where the content provider is operating (Santiago

agreement)..$^{34}$

The Commission advocates the Simulcasting model of competition between collecting societies. This will be further discussed below.

\section{Abuse of a dominant position (Art. 82 issues)}

There is widespread consensus that collecting societies occupy a dominant position in their national markets. In many cases, single national markets have been ruled to be a 'substantial part' of the common market within the meaning of Article 82.35

The Article 82 case law on collecting societies falls into two groups: abusive conduct towards members, and abusive conduct towards users. These will be summarised in turn.

\section{Members}

- Collecting societies cannot discriminate on grounds of nationality. ${ }^{36}$

\footnotetext{
${ }^{34}$ The Santiago agreement is an agreement between the major music performing right author societies to license community-wide transmission by electronic means, including web-casting and on-demand services. It was notified to the Commission under Regulation 17 in April 2001. The Commission opened proceedings in May 2004, transforming the process into an 'own initiative procedure' under Regulation 1/2003. The Commission believes that users should not be forced to choose a licence from the collecting society controlling their territory, if an alternative licence was viable (Speech by Herbert Unger, Head of Media Division, DG Comp at European Cable Communication Association (ECCA), Brussels, 23 June 2004).

35 Collecting societies have been characterised as dominant by numerous national competition authorities: cf. German Bundeskartellamt, Verfügung vom 18.11.1960: GEMA as 'marktbeherrschendes Unternehmen'; Hübner and Stern [1978] 1997, p. 225; British Office of Fair Trading (OFT) (referral of the PRS to the Monopolies and Mergers Commission, 30 November 1994. In GVL v. Commission (Case 7/82, [1983] ECR 483, [1983] CMLR 645), German music performers' and record producers' society GVL made an unsuccessful attempt to argue that the market for rights exploitation services should be defined to include promoters and record companies. The EJC ruled that for the management of secondary rights vested in performing artists and record manufacturers, GVL had a de facto monopoly. Dominance in a single member state was deemed to be a substantial part of the common market in BRT v. SABAM (Case 127/73, Belgische Radio en Televisie v. SV SABAM and NV Fonior, [1974] ECR 313, [1974] 2 CMLR 238).

${ }^{36}$ Membership and collection cannot be restricted to domestic citizens or residents (GEMA I, OJ L134/15, decision of 20 June 1971; Phil Collins v. IMTRAT Handels GmbH). Foreign members (authors and publishers) cannot be excluded from participating in the governance of a society, nor from socio-cultural benefits $(G V L)$.
} 
- There can be no preferential treatment for groups of members, but threshold conditions to full membership, and distribution variations according to genre and cultural value have been tolerated. ${ }^{37}$

- There must be maximum freedom for members to decide which repertoire to inject into collective administration. However, collecting societies can insist on transfer of whole groups of rights, and rights in future works if that is indispensable to the operation of the society. ${ }^{38}$

- Right holders must be able to withdraw from membership, and assign their repertoire elsewhere. Collecting societies can insist on lengthy notice periods. ${ }^{39}$

- Collecting societies can limit the influence of members who are economically dependent on users (i.e. if a publisher is part of the same parent company as a record label). However the least restrictive measure has to be adopted. ${ }^{40}$

- There is no specific ECJ case law on the freedom (or otherwise) of collecting societies to refuse the administration of individual rights and right-holders. ${ }^{41}$

- There is no ECJ case law on the legitimacy of socio-cultural deductions.

Users

- As a dominant undertaking, a collecting society cannot refuse to license a user in its own territory without a legitimate reason. ${ }^{42}$

37 GEMA II (decision of 6 July 1972, OJ L166/22). However, there is a recent policy trend requiring that royalty distribution must match actual use as closely as possible (MMC report on PRS, 1996; COM 261). There is no case law to that effect.

38 A required blanket assignment of all present and future rights was ruled to be abusive in $B R T v$. $S A B A M$. In GEMA I, the Commission identified seven categories of rights members may assign separately: (1) public performance, (2) broadcasting, (3) film performance, (4) mechanical reproduction, (5) film synchronisation, (6) video reproduction and performance, (7) new categories of right. The MMC report on the PRS (1996) added for the UK the rights to live performances. A mandatory requirement to assign on-line exploitation was held to be an unfair trading condition under Art. 82(a) (Daftpunk decision, Case C2/37.219, Banghalter et Homem Christo v. SACEM, 6 August 2002). Authors also must be able to assign different groups of rights to different societies in different countries (Case 22/79, Greenwich Film Production, Paris v. SACEM, [1979] ECR 3275, [1980] 1 CMLR 629). However, collecting societies can resist cherry-picking (for example, only having those rights assigned that are expensive to administrate).

${ }^{39}$ In GEMA II, the commission allowed a minimum membership term of three years. Retaining right for five years after a member's withdrew is likely to be unfair (BRT v. SABAM).

${ }^{40}$ For example, conditions on the exercise of votes are acceptable, exclusions from membership are $\operatorname{not}(G E M A$ I). Restrictions can be imposed that strengthen a society's negotiation power toward users (SABAM, para. 9). In GEMA III (OJ L94 /12, decision of 4 December 1981), the Commission authorised the societies statutes imposing uniform effective rates of renumeration (thus preventing members from making payments to users).

41 The general Article 82 case law on refusal to supply applies (e.g. Cases 6 and 7/73, ICI and Commercial Solvents v. Commission, [1974] ECR 223, [1974] 1CMLR 309; Magill: Cases C241\&2/91, RTE \& ITP v. Commission [1995] ECR 1-743; [1995] 4 CMLR 586). Some national laws provide for a duty to administer rights for all nationals or residents of EU and EEA states (e.g. the German law regulating copyright societies - §6 WahrnG, so-called Wahrnehmungszwang).

42 There are no specific rulings on refusal to license with respect to collecting societies. Again, the general Article 82 case law on refusal to supply applies (supra note Solvents v. Commission). 
- Refusal to license only part of the repertoire is acceptable if necessary for functioning of a society. ${ }^{43}$

- Excessive pricing of licences is abusive but hard to prove. ${ }^{44}$

- Price discrimination between large and small users has been raised as an abusive trading condition, but the Court did not rule on the point. ${ }^{45}$

- There is no ECJ case law on the nature, or lack of an appeals procedure making tariffs contestable. ${ }^{46}$

- There is no ECJ case law requiring introduction of competition between societies. ${ }^{47}$

It appears that the European Courts accept trading conditions with respect to collecting societies that would be considered abusive in many other contexts. ${ }^{48}$ The main line of reasoning is a familiar principle of proportionality: restrictive conditions are justified if they are required for the society to carry out its activities on the necessary scale. Yet, there is no explication about the function of collective administration beyond managing private interests. What are the activities that are necessary? The ECJ has tolerated, not always consistently, a number of practices relating to collective bargaining, licensing conditions and redistribution of royalties that can only be justified on social and cultural policy grounds.

43 In the French Discothèques cases (Lucazeau, Tournier), the impracticability of setting up a monitoring system in the foreign territory was deemed an acceptable reason.

${ }^{44}$ If tariffs in other member states are appreciably different, the collecting society needs 'to justify such a difference by reference to objective and relevant dissimilarities between copyright management' (Lucazeau, para 33). Including a mechanical fee for public performances in a discotheque is acceptable in the context of differences in national licensing systems (Case 402/85, Basset v. SACEM, [1987] ECR 1747, [1987] 3 CMLR 173).

45 In the French Discothèques cases (Lucazeau, Tournier), the appellants complained that large scale users, such as radio and TV broadcasters, obtained lower tariffs. Stamatoudi argues that the line of cases on price discrimination looks at clients in competition to each other, not treating customers in different situations in the same way. I.A. Stamatoudi, 'The European Court's Love-Hate Relationship with Collecting Societies’ (1997), 19(6) European Intellectual Property Review 289-297.

46 According to AG Jacobs in Tournier, the fact that there is no regulatory control of the price charged by a society is relevant. For discussion, see Temple Lang 1998, p. 57. Germany and the UK are the only EU countries with a formalised appeals procedure. For analyses of the jurisprudence of the UK Copyright Tribunal, see W. Cornish and D. Llewelyn Intellectual Property ( $5^{\text {th }}$ ed.) (London: Sweet \& Maxwell 2003), sections 12-54 to 12-58; L. Bently and B. Sherman Intellectual Property Law ( $2^{\text {nd }}$ ed.) (Oxford: OUP, 2004), pp. 286-7.

47 The French Discothèques cases (Lucazeau, Tournier) hint at problems with SACEM's administrative overheads due to lack of competition, but left the issue to national regulation.

48 At the Cambridge workshop, Professor Rosa Greaves (Glasgow University) suggested that ECJ case law on the collecting societies may have evolved in response to similar issues as the jurisprudence on shipping liner conferences (e.g. Compagnie Maritime Belge Transports SA v. Commission (Cases C395/96P, C-396/96P) [2000] ECR II-1365; [2000] CMLR 1076. A comparison would appear fruitful. 


\section{Regulatory Intervention}

I have argued that collecting societies provide a function beyond private joint ventures between right owners aimed at minimising their own transaction costs, a position recognised in some but not all of EC competition jurisprudence. Where such a function is cited in case law, there is insufficient development of the concepts supporting this function. In this section, I shall develop a more coherent doctrine of collective administration of copyright from an analysis of policy interventions by the European Commission.

\section{Community-wide licensing and good governance}

The Commission has justified recent policy moves on the collective management of copyright as a response to the rapid emergence of a digitised environment since the mid-1990s. According to Charlie McCreevy (the Internal Market and Services Commissioner of the Barroso Commission), 'Europe's model of copyright clearance belongs more to the nineteenth century than to the $21^{\text {st }}$. Once upon a time it may have made sense for the member state to be the basic unit of division. The internet overturns that premise. In the nineteenth century, music was primarily performed in cafés, bars or music halls that needed to be monitored locally by local societies. But this is no longer the only or even the most important way the Europeans consume music.' 49

Technological factors which affect the rationale of the European structure of collective administration include:

(i) the increased possibilities of individual licensing, using digital rights management technologies (DRM); ${ }^{50}$

(ii) the borderless nature of Internet-based services (such as web-casting, streaming and downloads), creating a demand for Community-wide licensing. ${ }^{51}$

\footnotetext{
49 Speech/05/588 'Commission recommendation on management of online rights in musical works' at the UK Presidency Conference on Copyright and the Creative Economy (7 October 2005).

50 'DRM systems can be used to clear rights, secure payments, to trace behaviour and to enforce rights' (COM 261, para 1.2.5). Examples include Windows Media Player and the 'Fairplay' system incorporated in Apple's iTunes service. The technology (using an encryption/decryption algorithm and meta data audit trails) allows the content provider to prescribe detailed conditions of usage. According to Article 5(2)(b) of the Information Society Directive (2001/29), copyright levies for unauthorised
} 
Under various Internal Market and Competition Commissioners, as well as Heads of the Copyright unit, the Commission has made numerous attempts to regulate Collecting Societies since the 1995 Green Paper on Copyright an Related Rights in the Information Society (COM(95) 382). Over the next decade, stops, starts, and turnabouts have been too numerous to record here in detail. However, during 2004 a new policy to liberalise the market for rights administration services began to emerge, first as an option in Communication (COM(2004) 261) The Management of Copyright and Related Rights in the Internal Market, then as choice with the publication of the Study on a Community Initiative on the Cross-Border Collective Management of Copyright (7 July 2005), and finally as a Commission Recommendation On the Collective Cross-border Management of Copyright and Related Rights for Legitimate Online Music Services (adopted 12 October 2005), a new 'soft law' instrument addressed 'to the Member States and to all economic operators which are involved in the management of copyright and related rights'. Following an unspecified period of close monitoring (thought to be about four years), a more binding legislative approach might be considered.52

The introduction of market choices in the form of competition between collecting societies has been summarised as a simple two-fold prescription:

- Right owners must have a choice in selecting their protector. They should have the choice of the collecting society they select to license their rights.

private use (compensating right holders in many European countries via collecting societies) must take account 'of the application or non-application of technological measures'.

51 The Commission Study on a Community Initiative on the Cross-Border Collective Management of Copyright (7 July 2005) contrasts revenues for 2004 from online music services in Western Europe of $€ 27.22$ million (of which $€ 23.4 \mathrm{~m}$ are attributable to downloads and $€ 3.8 \mathrm{~m}$ to subscription-based services) with US online music revenues of $€ 207$ million (of which $€ 155.9 \mathrm{~m}$ are attributable to downloads and $€ 51.1 \mathrm{~m}$ to subscription-based services), blaming a 'lack of innovative and dynamic structures for the cross-border collective management of legitimate online music services' (p. 6) as 'a commercial users requires a licence from each and every relevant collective rights manager in each territory of the EU in which the work is accessible' (p. 8).

52 COM 261 was published on 16 April 2004, and the consultation process closed in June 2004. A draft directive was scheduled for early 2005, and repeatedly postponed. On 7 July 2005, a study was published on how copyright for musical works is licensed for Internet use, and a press release announced Community action requiring cross-border management of copyright. The new 'soft law' approach in form of a Commission Recommendation was announced by McCreevy at the UK Presidency Conference on Copyright and the Creative Economy on 7 October 2005. 
- Users should have the choice of the one stop shopping platform when acquiring the licences for the rights for regional and global operation. ${ }^{53}$

However, at closer inspection the prescription is anything but simple. The first implementation decision relates to the nature of competition to be introduced. Will it be price competition (i.e. are users able to negotiate tariffs individually with the societies of their choice), or will there be a collectively set Europe-wide tariff (such as for the mechanical reproduction right which record producers are already able to clear with one collecting society of their choice) ${ }^{54}$ In the first scenario, users will seek a licence from the society with whom they can negotiate the cheapest tariff; in the second scenario, users individually cannot change the tariff structure, and competition takes place between societies only for services to right holders. ${ }^{55}$

The second implementation decision relates to the distribution rules operated by various societies. A prominent example are the different royalty shares allocated to authors and publishers in music performing right and mechanical societies, varying between 70:30, 60:40, 50:50 or individually negotiated rates. Thus all authors should wish to join societies with generous distribution rules, while publishers would opt for low or individually negotiated rates reflecting their superior commercial bargaining power. Will publishers be able to force author friendly societies to change their distribution rules? ${ }^{56}$

The most important provisions of the Commission Recommendation (Provisions 3-9) focus on introducing community wide licensing by giving right-holders the freedom to override reciprocal contracts between societies. Blanket assignments of 'all utilisation forms' (including various on-line exploitations) are deemed no longer

\footnotetext{
53 Ungerer, Herbert (2004), 'Competition law and rights management', speech at Regulatory Forum, European Cable Comunication Association (ECCA), Brussels, 23 June 2004 [available at europa.eu.int/comm/competition/speeches/index_theme_26.html].

${ }^{54}$ For discussion, see R. Wallis, C. Baden-Fuller, M. Kretschmer, G.M. Klimis 'Contested Collective Administration of Intellectual Property Rights in Music (1999), 14(1) European Journal of Communication 5-35.

55 This point was made to me by Professor Abraham Hollander, Dept. of Economics, Université de Montréal.

56 The Commission Study on a Community Initiative on the Cross-Border Collective Management of Copyright (7 July 2005) suggests that publishers should be able to exercise influence in any society they join according to the commercial value of the rights they administer.
} 
necessary. ${ }^{57}$ This follows the approach in the IFPI [Simulcasting] Decision that 'in new technology fields, territorial restrictions in the management of those rights are generally not acceptable, and must be reviewed' ${ }^{58}$ Price competition, and distribution rule competition are not discussed, either because the implications have not been seen, or perhaps because it is politically convenient to fudge the issue.

Other provisions relate to equitable ${ }^{59}$ distribution of royalties (Provisions 10-12), nondiscrimination of representation (Provision 13), accountability (Provision 14) and dispute resolution (Provision 15). These rules are aimed at improving governance (10-15) but similarly evade detail. Accountability and dispute settlement is primarily defined in relation to right-holders, not users - while COM 261 had stated explicitly (at 3.5.2) that under an appeals procedure '[i]t is essential for users to be in a position to contest the tariffs, be it through access to the courts, specially created mediation tribunals or with the assistance of public authorities which supervise the activities of collecting societies'.

The Commission Recommendation appears in line with a transaction cost rationale of collective administration. Authors, publishers, record labels or performers are conceptualised as one category, right-holders, and users are treated purely economically, regardless of whether they are engaged in a desirable cultural activity (say, small live venues), or act as a major multinational player (e.g. commercial radio station, record label, music TV). However, the main transaction cost user benefit, i.e. to be able to get all rights from one source, is thrown out.

Commissioner McCreevy anticipates that competition between collecting societies will lead to the evolution of 'attractive packages - repertoire', gathered by many different rights management services. ${ }^{60}$ The decision to use competition law

\footnotetext{
${ }^{57}$ In COM 261, the Communication had proposed (at para 3.4) to revisit the GEMA I categories of rights, owners may withhold.

58 Supra note_. H. Ungerer, 'Competition Law and Rights Management', speech at Regulatory Forum, European Cable Comunication Association (ECCA), Brussels, 23 June 2004 [available at europa.eu.int/comm/competition/speeches/index_theme_26.html].

59 'Equitable' here means only 'transparent'. In a newsletter article, the Head of the Copyright unit, emphasised the need for transparent distribution of royalties to other countries within the EU (T. Lüder, 'Copyright at the Crossroads?' DG Internal Market Newsletter, May 2005).

60 Speech 05/588, supra note
} 
principles in order to revamp collective administration may succeed in pressing collecting societies into speedier and more accurate business processes, lowering overheads - thus increasing productive efficiency. However, offering a choice to licensors and licensees (who continuously assess the transaction costs of multiple contracting) may support not a universal service system (to which all right holders have access on equitable terms), but a system where the major right holders and users selectively decide, supported by sophisticated information technology, whether administering collectively is worthwhile - and if so, which collecting society to use. ${ }^{61}$ Niche repertoire may be abandoned, as it is more expensive to monitor, collect and distribute than broadcasters' play lists. Distribution shares in favour of authors will come under market pressure from publishers.

Depending on these details, competition between collecting societies may have the following consequences (which could be analysed as a move away from a 'solidarity' rationale of collective administration):

- major users will be able to reduce their licensing tariffs as they negotiate with competing collecting societies

- major right holders will inject rights into the society that distributes most to them (or will not inject at all)

- publishers' influence within collecting societies will increase

- collecting societies will have few incentives to offer low start-up tariffs to small, innovative users

- cross-subsidies in the distribution of licence fees between big and small right holders will be phased out

- socio-cultural deductions for the benefits of domestic creators will come under pressure

- discrimination between genres will disappear

\footnotetext{
${ }^{61}$ I have discussed this in more detail in my 2002 paper 'The Failure of Property Rules in Collective Administration', 24(3) European Intellectual Property Review 126-136, at 133. Compare also [Wallis, Baden-Fuller, Kretschmer, Klimis 1999 supra note]. The idea has been around for some time (Besen and Kirby 1989 [supra note_] attribute it to Paul Goldstein (at note 8). It is also the solution advocated by Katz [supra note__].
} 
Increasing the transparency of collective administration, and requiring cross-border administration and licences (using competition law tools) paradoxically may increase the influence of major users and right holders (in effect reducing competition).

\section{Alternative policy principles}

The policy interventions advanced by the European Commission are not explicit about whether competition in the market for rights exploitation services is an aim in itself, or a means to shake up the bureaucracy of collecting societies while preserving non-economic goals. Within the framework of Community competencies, noneconomic aims are hard to articulate. Thus the Commission's preference for the language of competition is understandable. ${ }^{62}$ Still, better policy making has to start with a clear statement of regulatory aims.

COM 261 begun with a salutation of non-economic aims: 'Besides the more general economic aims of stimulating investment, growth and job creation, copyright protection serves non-economic objectives, in particular creativity, cultural diversity, cultural identity' (para 1.1.1). However, as discussed in the previous section, the measures proposed are couched in the competition law language of 'nondiscrimination', 'efficiency', 'rationalisation' and 'transparency' (see particularly Recitals 9, 10, 12 and 13).

In this final section I argue that the collective administration of copyright and competition law are two distinct, but partially overlapping mechanisms that ought to foster two aims.

\section{Access}

Copyright law awards broad exclusive rights for long periods of time (in Europe, the term is 70 years post mortem auctoris; 50 years for the related rights of producers and performers). This may hinder the introduction of new services, and

\footnotetext{
62 In recent years, European competition policy has recognised other policy goals only to the extent that they can be 'subsumed' under economic efficiency. For discussion, see G. Monti, 'Article 81 EC and Public Policy’ (2002), 39 CMLRev 1057
} 
lead to an under-utilization of copyright works. ${ }^{63}$ Collective licensing may provide a solution here, in effect replacing exclusive rights with a right to remuneration.

\section{Reward}

Although the copyright term is derived from the author's life, in commercial practice it is usually assigned to a market intermediary for exploitation. The terms of copyright contracts tend to favour best-selling authors. Diversity of cultural production will benefit from a reward system that is accessible to niche creators and allows for collective bargaining. ${ }^{64}$

Despite the noise generated by the lobbying efforts of major right holders and users (often focussing on 'piracy'), a consensus on these two regulatory aims is achievable. It can be backed up by first principles laid down in instruments such as the UNESCO Convention on Cultural Diversity ${ }^{65}$, and the social and cultural articles of the EC Treaty.

\section{How to articulate access aims?}

The aims of a regime of collective administration to provide access is to a considerable extent congruent with competition law aims, as the discussion on the 'refusal to supply' jurisprudence in section two above indicated. However, the hurdle for examining the exploitation of copyright under the Magill test is high. ${ }^{66}$ Although exclusive right owner choice in exercising copyright and related rights may not be

\footnotetext{
${ }^{63}$ For a discussion of 'under-utilization resulting from copyright protection in the presence of market power', see T. Gallagher, 'Copyright Compulsory Licensing and Incentives', in Copyright in the Cultural Industries, ed. R. Towse (Cheltenham: Edward Elgar, 2002), pp. 85-98. It could also be argued that copyright law facilitates concentration processes as incumbent firms reap the benefits of an extended backcatalogue of copyright protected contents.

${ }^{64}$ I have considered the empirical effects of music copyright contracts in M. Kretschmer, G.M. Klimis, R. Wallis, 'The Changing Location of Intellectual Property Rights in Music: A study of music publishers, collecting societies and media conglomerates' (1999) 17(2) Prometheus 163-186 and M. Kretschmer, 'Artists' Earnings and Copyright: A review of British and German music industry data in the context of digital technologies' (2005) 10(1) First Monday (www.firstmonday.org) pp. 1-20.

65 The UNESCO Convention on the Protection and Promotion of the Diversity of Cultural Expressions (adopted on 20 October 2005) came into force on 18 March 2007. In an unprecedented move, the EU ratified the Convention as a regional organization of economic integration.
} 
conducive to the development of new digital markets, the rules of competition are a cumbersome means for solving this generic problem of copyright. ${ }^{67}$

In considering regulating access through a regime of collective administration, attention must be paid to international copyright obligations. Under the 1994 WTO TRIPS Agreement and the 1996 WIPO Internet Treaties, exceptions or limitations to exclusive rights must be confined to 'certain special cases which do not conflict with the normal exploitation of the work and do not unreasonably prejudice the legitimate interests of the right holder' ${ }^{68}$ One technique open to legislators is to use the concept of 'extended licensing' to achieve very similar effects to a 'compulsory licence'. For the so-called Internet right ('communication to the public, including making available on demand', Art. 3 Info Soc Directive 2001/29) COM 261 considered and rejected two options (i) compulsory licences, (ii) legislating that a licence issued in any member state on the Internet right covers all territories. ${ }^{69}$

\footnotetext{
66 Finding of a dominant position plus failing to meet demand for a new product for which there is no substitute (and there is no objective justification for refusing to licence)

${ }^{67}$ An alternative would be fairly radical re-casting of competition concepts. At the Munich workshop, Professor Josef Drexl advocated a shift from 'allocative efficiency' focussing on price and output to the dynamic concept of 'creative competition' which, in the sphere of copyright, should ensure equal market access to all copyright works (cf. J. Drexl 'Competition in the Field of Collective Management: Preferring 'creative competition' to 'allocative efficiency' in European copyright law', in P. Torremans (ed.) Handbook on European Copyright Law (2007). Drexl's approach arrives from different premises at very similar policy recommendations to my own.

68 The so-called three-step-test is taken from Article 9(2) of the Berne Convention where it defines permitted exceptions to the reproduction right only. Note that under Berne, the three-step-test does only apply to the reproduction right. However, Art. 13 of the TRIPS Agreement (1994) and Art. 10 of the WIPO Copyright Treaty (1996) make the test applicable to all copyright limitations and exceptions.

${ }^{69}$ According to COM 261, such prescriptions would be at variance with the intellectual property principles on territoriality and possibly with international obligations (WIPO 1996 Treaties, establishing the Internet right as an exclusive right: 'making available to the public... in such a manner that members of the public may access these works from a place and at a time individually chosen by them'; Art. 8, WIPO Copyright Treaty; Arts. 10 and 14, WIPO Performances and Phonograms Treaty). Many commentators think that under the Berne three-step-test, collective management can only be compulsory if right holders have no other viable way to exercise an exclusive right. Under a system of extended licensing (used for example in Norway, Sweden, Denmark, Iceland), 'as soon as a substantial number of right holders of a certain category agree to participate in a collective scheme, the scheme is automatically extended not only to other national right holders in the same category, but to all foreign ones as well' (Gervais, supra note , at 29).
} 


\section{How to articulate reward aims?}

Facilitating the reward of creators beyond their individual bargaining power in cultural markets relies on a non-economic justification that appears to be at variance with competition law's emphasis on allocative efficiency. But note that EC competition jurisprudence has recognized the social benefits of collective bargaining, exempting some practices from examination under the rules of competition (for discussion of Albany and Brentjens, see section two above).

In developing single market and competition policies, the Commission is also obliged to take account of cultural aspects (Art. 151 EC). Fostering cultural diversity through the encouragement of creators at the margins of commercial viability, creators in smaller domestic markets, and creators in niche cultures is a defensible Community aim that can influence the regulation of copyright management services.

\section{Which Community instruments should be used to regulate collecting societies?}

Any intervention can legitimately draw on single market concerns. As COM states (at para 1.2.3): 'A lack of common rules regarding the governance of collecting societies may potentially be detrimental to both users and right holders, as it may expose them through different conditions applying in various Member States, as well as to a lack of transparency and legal certainty. The more divergence exists on such rules, the more difficult it is in principle to license across borders and to establish licensing for the territory of several or all Member States.' The justification of intervention can also point to competition concerns, identifying collecting societies as dominant undertakings (as the sole provider of a management infrastructure to right holders, and as the only supplier of licences to copyright users). In line with the proposals of COM 261, tariffs need to become transparent and contestable, as should be the distribution of fees collected. In effect, the collective administration of copyright can no longer be at the discretion of right owners. Consumers and users should be involved in the regulation of collective copyright management services.

A major concern of the Commission appears to be the onerous nature of seeking Community-wide licences. Rather than regulating for pan-European licences directly, or giving right holders and users the choice between collecting societies competing for pan-European business, tighter regulatory control itself (including the review of 
tariffs and distributions) could deliver acceptable pan-European licences that do not favour the major right holders and users only. ${ }^{70}$

\section{Criteria for the re-assessment of current licensing tariffs and distributions}

Having delivered a governance structure that can meaningfully review tariffs and distributions, the attention needs to turn to the criteria to be used in setting tariffs and distributions. This is a thorny area where the experience of countries with a central copyright board may be helpful. Often proxies are sought, seeking to simulate agreements between willing buyers and sellers. Measures of substitutability suggested for the assessment of tariffs include audience ratings, advertisers' willingness to pay, broadcasters' willingness to pay, viewers' willingness to pay under pay-per-view. ${ }^{71}$

It is submitted that tariffs and distributions should be reviewed not merely from proxies of willing individual sellers and buyers (the transaction cost rationale) but also under a framework of socio-cultural aims. For reasons outlined above, this may exceed Community competencies and therefore has a more natural home in the domestic social and cultural policies of Member States. However, this poses a problem for information services (such as digital downloads of music files) that increasingly take place in a single European market. ${ }^{72}$ Central licensing agreements between major right holders and users negotiated at pan-European level will have pan-European social and cultural consequences. Which regulator will supervise these?

\footnotetext{
70 One proposal, still within the remit of competition law, would be to recast collective administration as an 'essential facility' (Temple Lang supra note__, p. 59): 'A single Community society could achieve the same results more efficiently than the present over-complex structure, and might not be significantly less competitive.'

71 The Canadian experience is usefully summarised in Y.A. George Hynna 'Evolution of Judicial Review of Decisions of The Copyright Board'. In SENA (Case C-245/00 [2003] ECR I-1251), the European Court of Justice developed the meaning of the Community concept of 'equitable remuneration' as an assessment 'in the light of the value of that use in trade' (para 37). The method chosen by the Member States must be 'such as to enable a proper balance to be achieved between the interests of performing artists and producers in obtaining remuneration for the broadcast of a particular phonogram, and the interests of third parties in being able to broadcast the phonogram on terms that are reasonable' (para 36).

72 For example, under a deal announced in January 2007, EMI Music Publishing, PRS and GEMA will form a new company CELAS which will be the only source of licences for EMI repertoire for online and mobile usage within 41 European territories (www.celas.eu).
} 
The tension between Community and national perspectives is most acute with respect to three issues. Here, competition law can offer few solutions:

- Collecting societies extract too heavily from fragmented users (such as clubs, concert venues and smaller websites) where the societies' bargaining power is high and collection is expensive. This is inefficient, as well as introducing an undesirable bias against diverse and local cultures. Live performances in small venues and schools should be encouraged: 'contemporary' material should not be significantly more expensive than 'classical' works. Taking account of these cultural imperatives, collection should concentrate on the major commercial users (where the societies' bargaining power and fees are under pressure in a system that may facilitate user choice).

- Licences permitting free use must be possible. The blanket assignment of rights to collecting societies has become a problem for initiatives that wish to offer authors more options in authorising transformative and non-commercial use of copyright works. ${ }^{73}$ Administratively this creates a similar challenge for collecting societies as the partial withdrawal of repertoire by major right holders (the 'cherry-picking' problem). A solution that passes the onus of obtaining and proving clearance under non-standard conditions to users should avoid the additional costs which individually tailored licensing conditions would create for collective management bodies. ${ }^{74}$

- Distributions should include a socio-cultural element (e.g. cross-subsidy big $\rightarrow$ small; investor $\rightarrow$ creator; mainstream $\rightarrow$ niche; foreign $\rightarrow$ domestic). This proposition is at variance with the Commission's proposal to match distributions as closely as possible to actual use (and in particular improve the collecting and distribution for non-domestic right holders).

Regarding re-distribution in favour of smaller right holders, an economic justification may be available: Collecting societies are bodies authors join

\footnotetext{
73 The best-known initiative is Creative Commons (www.creativecommons.org).
} 
before they know who will be successful. The collective administration of copyright then can be conceptualised as an insurance scheme. ${ }^{75}$

With regard to the other proposed re-distributions, cultural arguments need to be mustered: It cannot be in the interest of countries whose consumers have come to rely heavily on (mostly) Anglo-American cultural imports, to perpetuate such a system by collecting and distributing domestic fees largely for the benefits of foreign right holders. Supporting a diverse domestic scene of cultural production is a legitimate aim of copyright policy, and a bias in the collective administration towards domestic creators appears entirely justifiable.

\section{Conclusion}

In this article, I have argued that the collective administration of copyrights should be conceived as an independent regulatory regime, ensuring access to and reward for creative materials. In pursuing these aims, policy makers should use the tools of competition law where they are available under current EC jurisprudence. Collecting societies are currently insufficiently accountable to society, and pursue many practices that are at variance with the aims of access and reward. Radical reform of their governance is needed. If collecting societies are to become facilitators of an information society, users will have to be represented in the supervisory structures, and tariffs and distribution rules need to be meaningfully reviewed in a public forum.

\footnotetext{
${ }^{74}$ In the medium term, DRM-type systems operating under the umbrella of collecting societies might become an alternative. The policy rule should be that right holders can alter blanket licensing conditions only in favour of more permissive use (this would address the 'cherry-picking' issue).

75 This interesting point was made in Montreal by Prof. Richard Watt (Universidad Autónoma de Madrid; cf. A. Snow and R. Watt 'Risk Sharing and the Distribution of Copyright Collective Income', pp. 23-36 in L.N. Takeyama, W.J. Gordon and R. Towse Developments in the Economics of Copyright Cheltenham: Edward Elgar 2005). New empirical data from a comparative survey of authors' earnings in Germany and the UK shows that, currently, the distribution of collecting societies payments is more skewed than income from rights that are individually managed. For collecting society income, the top 10 percent of writers receive about $60 \%$ (Germany) - 70\% (UK) of collecting society payments, while for total individual income from writing, the top 10 percent of writers account for $50 \%$ (Germany) $60 \%$ (UK) of total wealth - M. Kretschmer and P. Hardwick Authors' Earnings from Copyright and Non-Copyright Sources: A Survey of 25,000 British and German Writers (London: ALCS 2007). If membership in a collecting society should act as risk mitigation, writers need to agree a 'progressive' re-distribution of wealth from higher to lower earners.
} 
While governance rules are usefully regulated at Community level, the review of tariffs and distributions as far as possible must remain under domestic control. Member states ought to be able to express their diverse social and cultural priorities. However, where pan-European services make this impracticable (for example in the field of music), tariffs and distributions need to be supervised at pan-European level. As a first move, a public repository should be created of all collective management agreements with a European dimension, enabling public debate. As a second step, a European Copyright Board should be established under a constitution of Access and Reward (borrowing mechanisms from other regulated industries, such as utilities or broadcasting). ${ }^{76}$ The Board would be expected to develop jurisprudence on issues such as duty to contract, free use, socio-cultural deduction and so on.

The European Courts, and recent interventions by the Commission have evaded the analytical choice between the rules of competition (applying competition law to an hitherto sheltered sector of economic activity) and a sui generis regulatory regime beyond the rules of competition (taking account of wider socio-cultural aims). This article has outlined the implications for a European information society.

\footnotetext{
76 There is a tradition of contestable copyright tariffs particularly in the UK, Germany, Canada and the US. However, the remit of these quasi-judicial bodies tends to be narrow, with a standard of review seeking market emulation.
} 